\title{
Plant-produced chimeric virus-like particles - a new generation vaccine against African horse sickness
}

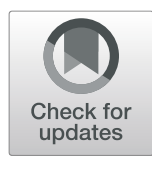

Daria A. Rutkowska ${ }^{1 *}$ D, Nobalanda B. Mokoena ${ }^{2}$, Tsepo L. Tsekoa ${ }^{1}$, Vusi S. Dibakwane ${ }^{2}$ and Martha M. O'Kennedy ${ }^{1}$

\begin{abstract}
Background: African horse sickness (AHS) is a severe arthropod-borne viral disease of equids, with a mortality rate of up to $95 \%$ in susceptible naive horses. Due to safety concerns with the current live, attenuated AHS vaccine, alternate safe and effective vaccination strategies such as virus-like particles (VLPS) are being investigated. Transient plant-based expression systems are a rapid and highly scalable means of producing such African horse sickness virus (AHSV) VLPS for vaccine purposes.

Results: In this study, we demonstrated that transient co-expression of the four AHSV capsid proteins in agroinfiltrated Nicotiana benthamiana dXT/FT plants not only allowed for the assembly of homogenous AHSV-1 VLPs but also single, double and triple chimeric VLPS, where one capsid protein originated from one AHS serotype and at least one other capsid protein originated from another AHS serotype. Following optimisation of a large scale VLP purification procedure, the safety and immunogenicity of the plant-produced, triple chimeric AHSV- 6 VLPs was confirmed in horses, the target species.

Conclusions: We have successfully shown assembly of single and double chimeric AHSV-7 VLPS, as well as triple chimeric AHSV-6 VLPS, in Nicotiana benthamiana dXT/FT plants. Plant produced chimeric AHSV-6 VLPs were found to be safe for administration into 6 month old foals as well as capable of eliciting a weak neutralizing humoral immune response in these target animals against homologous AHSV virus.
\end{abstract}

Keywords: Plant-expressed, Chimeric, Virus-like particle, VLP, Vaccine, African horse sickness, AHSV, Orbivirus

\section{Background}

African horse sickness (AHS) is a devastating disease of equids causing severe morbidity in naïve horses with the mortality rate up to 95\% [1]. Although donkeys, mules and zebras may also be infected, clinical signs in susceptible horses range from mild to high fever, severe respiratory problems, weight loss and lethargy in the acute form [2]. Although AHS is endemic to sub-Saharan Africa, outbreaks have also been reported in North Africa, the Iberian Peninsula, the Middle East and Asia and, due to climate change, there is an ever-increasing risk of the spread of the disease, and its vectors, to non-endemic countries [3]. The disease is included in the World Organisation for Animal Health (OIE) 2019 list of

\footnotetext{
* Correspondence: DRutkowska@csir.co.za

${ }^{1}$ CSIR Chemicals, PO Box 395, Pretoria 0001, South Africa

Full list of author information is available at the end of the article
}

notifiable animal diseases, resulting in strict quarantine measures governing the export of horses from endemic to non-endemic regions. This places a significant economic burden on the equine industries of affected countries.

African horse sickness virus (AHSV), the causative agent of AHS, is an Orbivirus in the family Reoviridae and is transmitted to susceptible animals via Culicoides midges [4]. The AHS virion is a $70 \mathrm{~nm}$ icosahedral, nonenveloped particle, composed of three concentric layers surrounding the segmented double-stranded RNA genome $[1,5]$. Like Bluetongue virus (BTV), the prototype Orbivirus [6], the subcore of AHSV is composed of 120 copies of structural protein VP3 and is covered by a layer of VP7 trimers forming the core particle. The core is surrounded by the outermost layer composed of structural proteins VP5 and VP2, with VP2 being the neutralizing antigen and serotype determinant [7-10]. There

(c) The Author(s). 2019 Open Access This article is distributed under the terms of the Creative Commons Attribution 4.0 International License (http://creativecommons.org/licenses/by/4.0/), which permits unrestricted use, distribution, and 
are nine AHSV serotypes present within South Africa and most parts of sub-Saharan Africa [1]. In these endemic regions, annual prophylactic vaccination of horses with a commercial live attenuated vaccine (Onderstepoort Biological Products (OBP)) is an efficient way of preventing serious losses during the peak AHS season [11]. There are, however, several drawbacks associated with the use of the current live AHS vaccine including the risk of reversion to virulence, genome segment reassortment between vaccine and field strains and teratogenic effects in pregnant mares $[2,12,13]$. There is also no way of differentiating between infected and vaccinated animals (DIVA). Thus there is an urgent need for safe, efficacious and cost-effective new generation vaccines against AHS for use in endemic as well as nonendemic countries. New AHS vaccine candidates, based on subunit vaccine, recombinant viral vectored vaccine and reverse genetics approaches have been developed but each have their own disadvantages and have not yet progressed to the market $[9,14-24]$.

Virus-like particles (VLPs) are considered a safe and effective alternative to live attenuated vaccines for many viral diseases [25]. These self-assembling particles, composed of viral structural proteins but lacking the viral genome, exhibit size and morphology very similar to that of native virions but are unable to replicate [25-28]. Such VLP-based vaccines are inherently safe because they are unable to replicate or reassort as they do not contain a genome and are DIVA-compliant due to their lack of non-structural proteins. Co-expression of BTV VP2, VP5, VP7 and VP3 capsid proteins in insect cells resulted in the assembly of VLPs capable of eliciting a long-lasting protective immune response against virulent BTV challenge in vaccinated sheep $[29,30]$. Recently coexpression of the four AHSV-9 capsid proteins in insect cells allowed for self-assembly of AHS VLPs [31]. However, the yield of these assembled AHS VLPs was very low, precluding their quantification. Due to the low yield and high costs associated with large scale production of Orbivirus VLPs in the insect cell expression system, it is unlikely that this expression system will be utilised to produce Orbivirus VLP-based vaccines, other than monovalent candidates, on a commercial scale.

Transient expression in plants is currently being employed for the fast and relatively easy production of VLPs, antibodies and other heteromultimeric complexes [32, 33]. Advantages of transient plant expression systems include speed, scalability, cost-effectiveness and safety [34-39]. Transient co-expression of the structural proteins of Bluetongue virus in plant cells [40, 41] allowed for the self-assembly of BTV-8 VLPs that elicited a protective immune response against virulent BTV8 challenge in sheep $[42,43]$. Recently, the four capsid proteins VP2, VP3, VP5 and VP7 of AHSV-5 were shown to self-assemble into homogenous VLPs when transiently expressed in Nicotiana benthamiana plants [44]. These plant-produced AHSV-5 VLPs were also shown to elicit strong neutralizing immune responses in both guinea pigs and horses [45]. An RNAi mutant dXT/FT $N$. benthamiana, which facilitates mammalianlike glycosylation [46] and may result in AHSV VLPs more closely resembling AHSV virions with authentic post translational modifications, is available in our laboratory.

As Orbiviruses are capable of genome segment reassortment, one of the strategies of generating serotypespecific VLP-based vaccine candidates is to exchange the outer capsid proteins VP2 and/or VP5 with those of a different serotype whilst retaining the conserved inner core (VP7 and VP3 proteins) of the original serotype $[47,48]$. This strategy of generating such 'chimeric' VLPs would reduce the number of constructs required and significantly simplify the process of generating a multivalent vaccine. Replication-deficient chimeric BTV and AHSV have recently been generated via a reverse genetics approach by exchanging specific gene segments with those of another serotype [49-52].

In this study, we report on the transient expression and self-assembly of both homogenous, as well as single, double and triple chimeric AHS VLPs in N. benthamiana $\mathrm{dXT} / \mathrm{FT}$ plants. We also demonstrate that plantproduced, chimeric AHSV-6 VLPs are safe and immunogenic in horses, the target species, and capable of eliciting neutralizing antibodies against homologous AHSV-6 virus.

\section{Results}

Transient capsid protein expression and assembly of chimeric AHS VLPs in plants

In order to facilitate the assembly of African horse sickness virus-like particles (VLPs) in $N$. benthamiana dXT/ FT plant cells, sequences encoding the AHS structural capsid proteins VP2, VP5, VP3 and VP7 were codonoptimised for $N$. benthamiana expression and cloned into either the pEAQ-HT or pEAQ-express plant expression vectors [40]. The AHSV-1 VP7 and VP3encoding genes were inserted into the same pEAQexpress vector to ensure co-expression and also reduce the number of recombinant plasmids required for coinfiltration.

$N$. benthamiana $\mathrm{dXT} / \mathrm{FT}$ leaves were infiltrated with different combinations of the recombinant Agrobacterium tumefaciens bacteria. In order to facilitate the assembly of the homogenous AHSV-1 VLPs, the pEAQHT-AHSV-1VP2, pEAQ-express-AHSV-1VP5 and pEAQ-express-AHSV-1VP7-AHSV-1VP3 plasmids were agroinfiltrated into $N$. benthamiana $\mathrm{dXT} / \mathrm{FT}$ leaves in a ratio of 1:1:1. Assembly of AHS core-like particles 
(CLPs) was facilitated by the agroinfiltration of the dual plasmid pEAQ-express-AHSV-1VP7-AHSV-1VP3. Infiltrated leaves were harvested 8 days post-infiltration, as previously reported for optimal BTV capsid protein transient expression [42, 43], and the leaf tissue extract centrifuged through sucrose density gradients. The presence of the AHSV-1 capsid proteins within the sucrose fractions was assessed by SDS-PAGE and immunoblotting with AHS serotype 7-specific antiserum (Fig. 1). The AHSV-7 antibodies bound to protein bands corresponding in size to the AHSV-1 VP3 (103.2KDa), VP5 $(56.6 \mathrm{KDa})$ and VP7 $(37.8 \mathrm{KDa})$ capsid proteins in the $55-35 \%$ sucrose fractions (Fig. 1, lanes 2-6). These bands were not visible in lanes $12-15$, containing $55-$ $40 \%$ sucrose fractions from the pEAQ-HT cell lysate gradient, the negative control. The identities of the AHSV-1 VP5, VP7 and VP3 proteins were confirmed using LC-MS/MS-based peptide sequencing. The presence of all three capsid proteins within the same sucrose fractions following centrifugation indicates that these proteins are assembling into high molecular weight particulate structures. Although not detected by the AHSV7 serotype-specific antiserum, the AHSV-1 VP2 neutralizing antigen $(123.6 \mathrm{KDa})$ is thought to be part of these particulate structures. To view these particulate structures, a sample of the $55 \%$ sucrose gradient fractions was stained with uranyl acetate and viewed under the transmission electron microscope (TEM) (Fig. 2a). The
AHSV-1 particulate structures resembled virus-like particles (VLPs) previously described [31]. These AHSV-1 VLPs were approximately $70 \mathrm{~nm}$ in diameter and appeared more densely populated than the 'spiky', knoblike surface of the $60 \mathrm{~nm}$ AHSV-1 core like particles (CLPs), consisting only of the VP7 and VP3 core proteins (Fig. 2b).

As AHS has nine serologically distinct serotypes, a multivalent vaccine is required in order to protect against this disease. Thus it was decided to exchange the outer capsid AHSV-1 VP2 protein with that of the AHSV-7 serotype whilst retaining the AHSV-1 VP5 and conserved AHSV-1 VP7 and VP3 core proteins. This strategy would reduce the number of constructs required and significantly simplify the process of generating a multivalent VLP-based AHS vaccine in plants. The pEAQ-HT-AHSV-7VP2, pEAQ-express-AHSV-1VP5 and pEAQ-express-AHSV-1VP7-AHSV-1VP3 plasmids were agroinfiltrated into $N$. benthamiana dXT/FT leaves in a ratio of 1:1:1. Infiltrated leaves were harvested 8 days post-infiltration, as previously, and the leaf tissue extract centrifuged through sucrose density gradients. The presence of the AHSV-1/AHSV-7 capsid proteins within the sucrose fractions was assessed by SDS-PAGE and immunoblotting with AHS serotype 7-specific antiserum (Fig. 1). Not only did the AHSV-7 antibodies bind to protein bands corresponding in size to the AHSV-1 VP3 $(103,2 \mathrm{KDa})$, VP5 $(56.6 \mathrm{KDa})$ and VP7 $(37.8 \mathrm{KDa})$ capsid

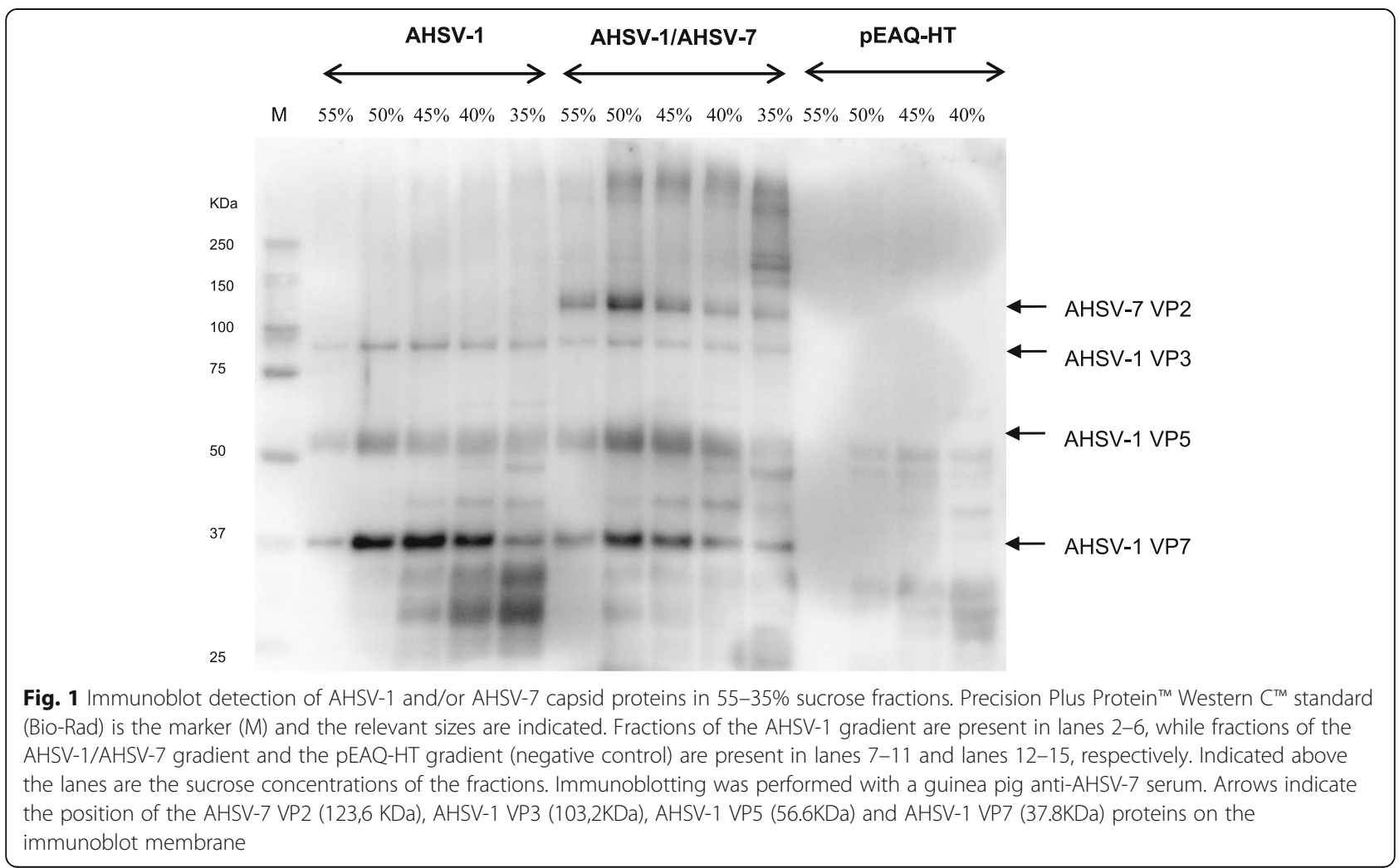


(a)

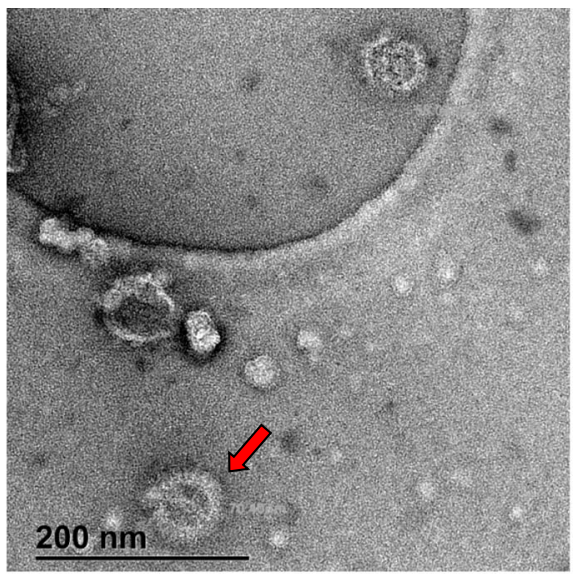

(c)

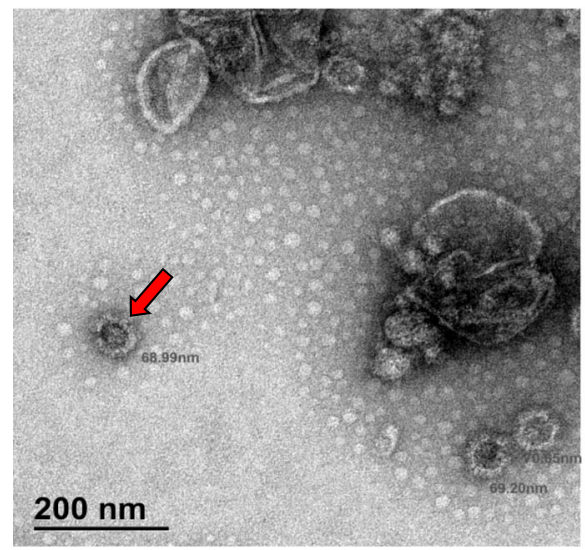

(e)

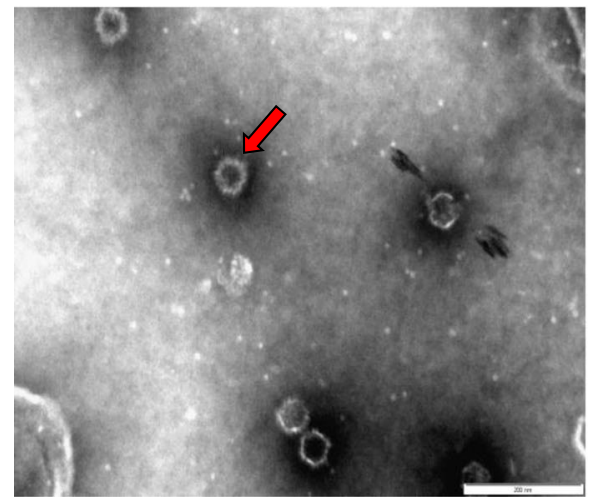

(b)

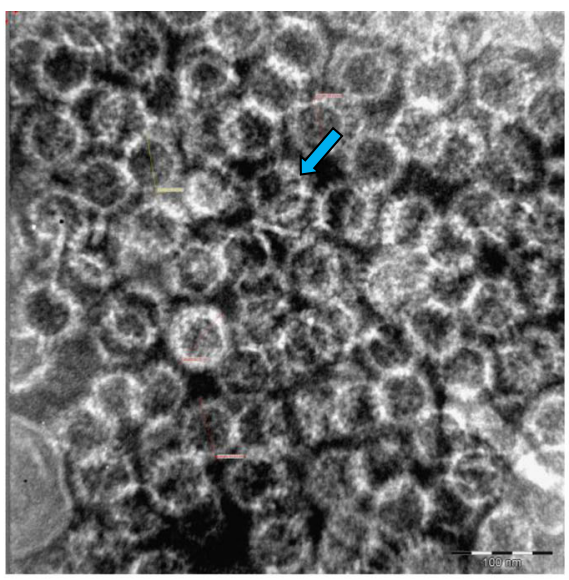

(d)

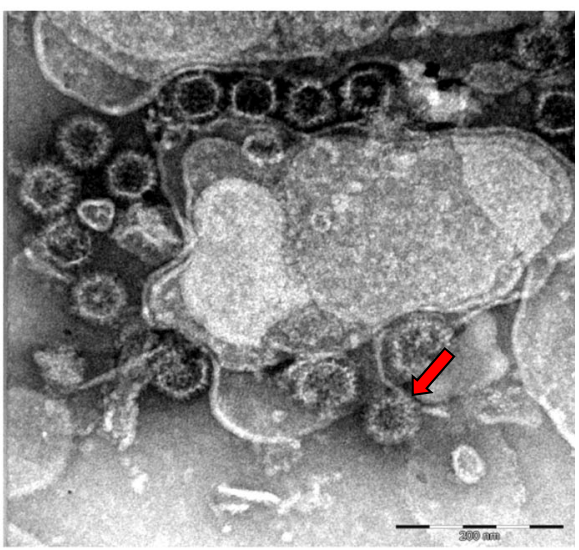

(f)



Fig. 2 Transmission electron microscope (TEM) images of density gradient purified AHSV-1 VLPS (a), AHSV-1 CLPs (b), chimeric AHSV-1/AHSV-7 VLPS (c), double chimeric AHSV-1/AHSV-7 VLPS (d) and triple chimeric AHSV-1/AHSV-6/AHSV-3 VLPS (e-f). Particles were visualized with a JEM-2100 Transmission electron microscope (JEOL). Indicated with red arrows are the virus-like particles (VLPs) and indicated with the blue arrow is a corelike particle (CLP)

proteins in the $55-35 \%$ sucrose fractions, but also to the band corresponding in size to the AHSV-7 VP2 neutralizing antigen (123.6 KDa) (Fig. 1, lanes 7-11). These bands were not visible in lanes $12-15$, containing 55$40 \%$ sucrose fractions from the pEAQ-HT cell lysate gradient, the negative control. The presence of all four capsid proteins in these sucrose fractions indicate their assembly into high molecular weight particulate structures. TEM visualisation of the particles in sucrose fraction 5 revealed the presence of densely structured single 
chimeric AHSV-1/AHSV-7 VLPs, approximately $70 \mathrm{~nm}$ in size (Fig. 2c).

Next, it was investigated whether both AHSV-1 outer capsid proteins VP2 and VP5 could be exchanged with those of AHSV-7 whilst allowing for the assembly of double chimeric AHS VLPs in plants. Genes encoding the AHSV-7 VP2 and VP5 proteins were co-infiltrated into $N$. benthamiana dXT/FT plant cells with those encoding the AHSV-1 VP3 and VP7 proteins. Single chimeric AHSV-1/AHSV-7 VLPs were expressed as a positive control. Following harvesting of the leaves 8 days post-infiltration, extraction and density gradient centrifugation, the presence of the AHSV capsid proteins within the sucrose fractions was confirmed by SDSPAGE and immunoblotting with AHS serotype 7specific antiserum (Fig. 3). Visualisation with the TEM confirmed the presence of double chimeric AHSV-1/ AHSV-7 VLPs, $70 \mathrm{~nm}$ in size (Fig. 2d).

We proceeded to investigate combining the VP2 and VP5 proteins of different serotypes with the AHSV-1 core proteins. In one of these experiments, the pEAQHT-AHSV-6VP2, pEAQ-HT-AHSV-3VP5 and pEAQ-
express-AHSV-1VP7-AHSV-1VP3 plasmids were agroinfiltrated into $N$. benthamiana dXT/FT leaves in a ratio of 1:1:1. Eight days post inoculation, infiltrated leaves were extracted in VLP dilution buffer and density gradient centrifugation, and the presence of the AHSV capsid proteins within the gradient fractions assessed by SDS-PAGE (Fig. 4). Protein bands corresponding in size to the AHSV-6 VP2 (123.6KDa), AHSV-3 VP5 (56.6KDa), AHSV-1 VP3 (103.2KDa) and AHSV-1 VP7 $(37.8 \mathrm{KDa})$ capsid proteins were observed in the $35-25 \%$ iodixanol fractions (Fig. 4, lanes 3-5). The identity of AHSV-6 VP2 protein band was confirmed by LC-MS/ MS-based peptide sequencing (Fig. 5). LC-MS/MS analysis of VP2 bands in lanes 4 and 5 (Fig. 4) resulted in $63.7 \%$ coverage for VP2, with 84 peptides identified with $>95 \%$ confidence, and $55.8 \%$ coverage for VP2, with 85 peptides identified with $>95 \%$ confidence in the VLPs produced, respectively.

The presence of all four AHS capsid proteins within the same density gradient fractions was indicative of their assembly into high molecular weight particles. Particles in the $30 \%$ iodixanol fraction were viewed via

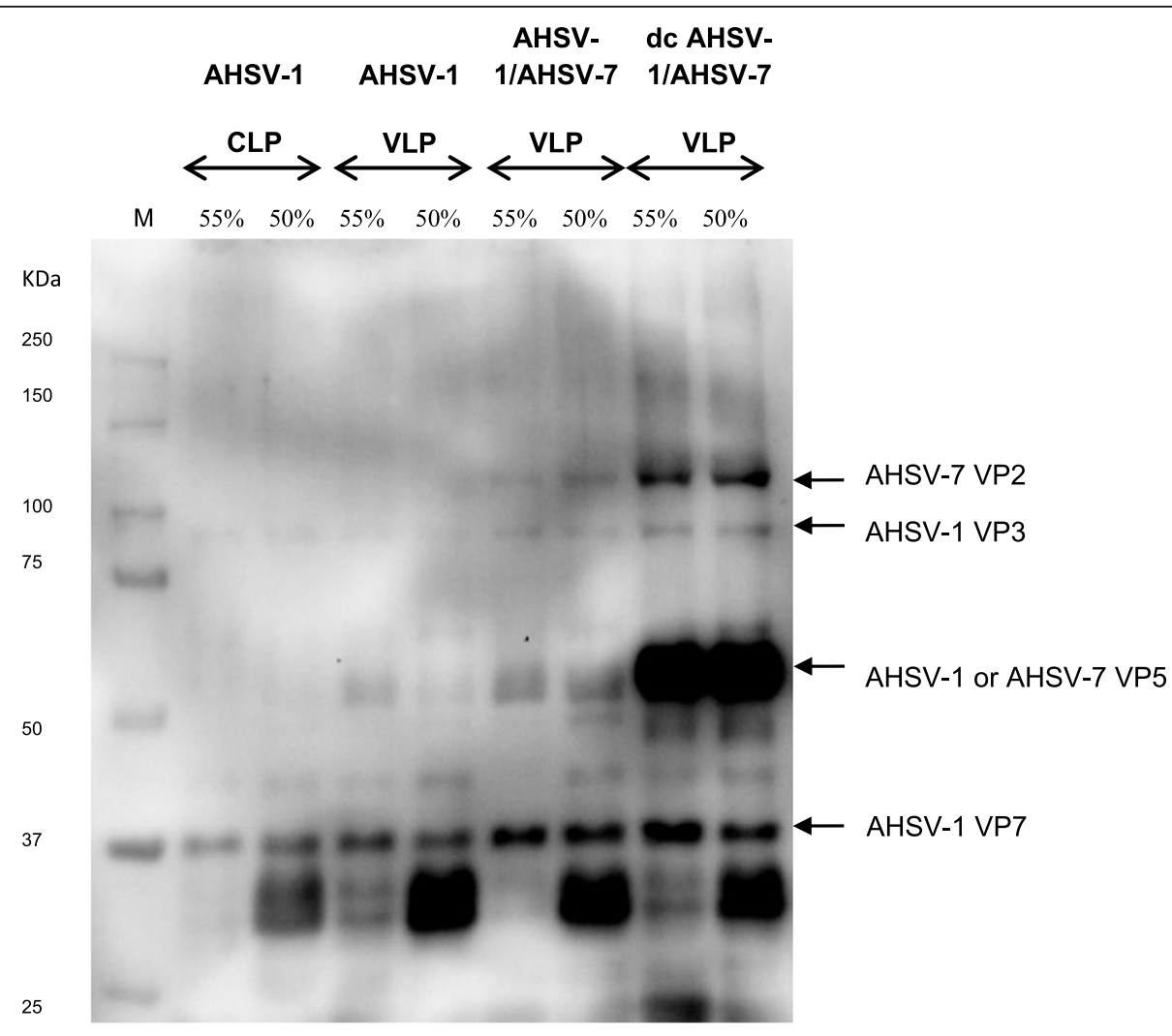

Fig. 3 Immunoblot detection of AHSV-1 and/or AHSV-7 capsid proteins in 55-50\% sucrose fractions. Precision Plus Protein ${ }^{\text {TM }}$ Western $C^{\text {TM }}$ standard (Bio-Rad) is the marker (M) and the relevant sizes are indicated. Fractions of the AHSV-1 CLP gradient, the AHSV-1 VLP gradient, chimeric AHSV-1/ AHSV-7 VLP gradient and double chimeric (dc) AHSV-1/AHSV-7 VLP gradient are present in lanes 2-3, 4-5, 6-7 and 8-9, respectively. Indicated above the lanes are the sucrose concentrations of the fractions. Immunoblotting was performed with a guinea pig anti-AHSV-7 serum. Arrows indicate the position of the AHSV-7 VP2 (123,6KDa), AHSV-1 VP3 (103.2KDa), AHSV-1 VP5 or AHSV-7 VP5 (56.6KDa) and AHSV-1 VP7 (37.8KDa) proteins on the immunoblot membrane 


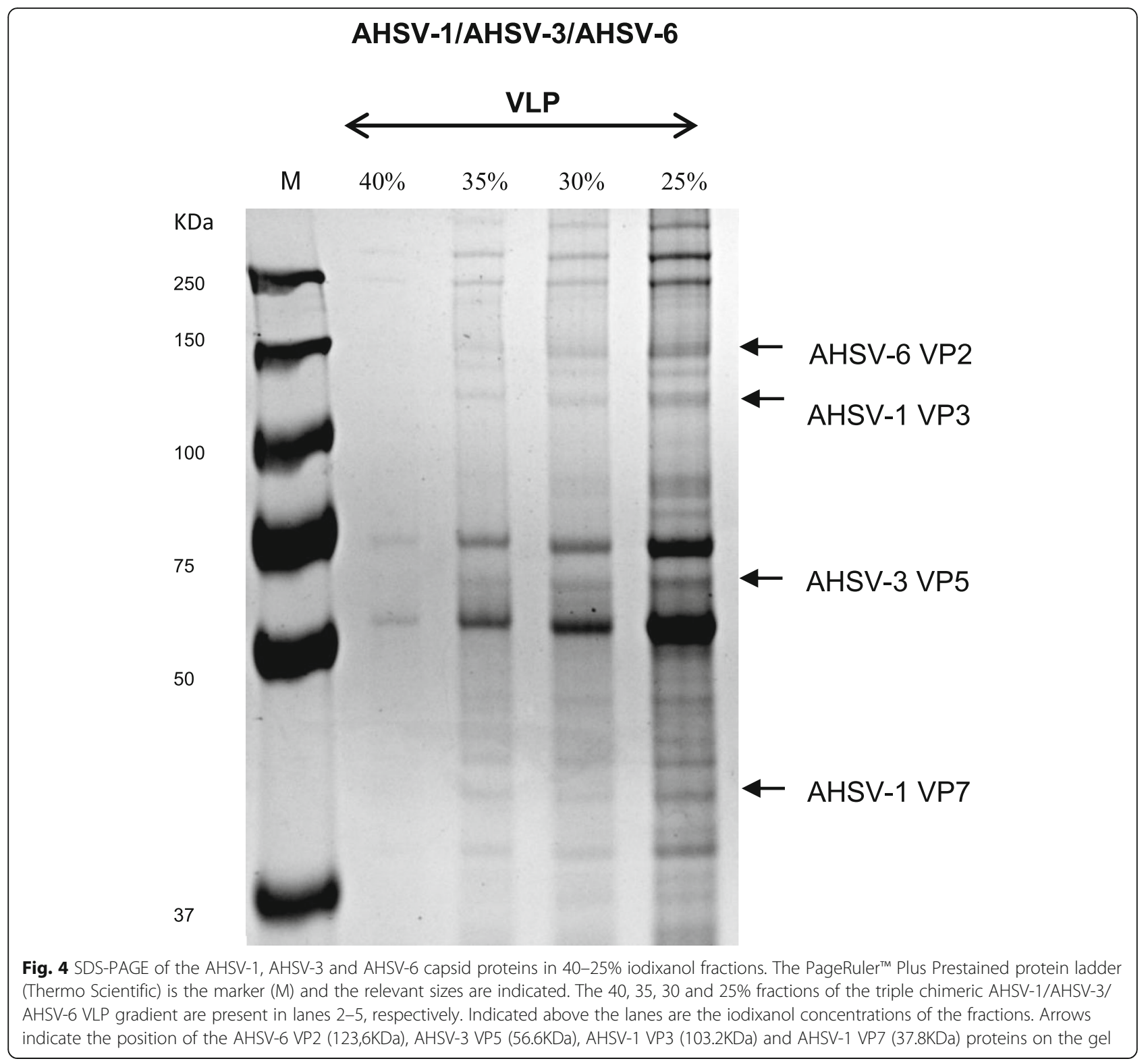

TEM (Fig. 2e-f). Triple chimeric VLPs, approximately $70 \mathrm{~nm}$ in size, were visualised.

\section{Safety and immunogenicity of plant-produced chimeric AHS VLPs in animals}

Plant-produced triple chimeric AHSV-1/AHSV-3/ AHSV-6 VLPs were purified using a combination of depth filtration and tangential flow filtration (TFF). The yield after filter sterilization was approximately $16 \mathrm{mg}$ VLPs per $\mathrm{kg}$ wet leaf weight as determined by BCA protein quantification of the filter-sterilized sample. These VLPs were demonstrated to be safe and immunogenic in horses. No lesions were observed at the site of injection and no side effects were identified as a result of administering either the VLP or Live attenuated vaccine (LAV).
The immune response induced by AHSV 6 VLP vaccine was variable (Table 1). The neutralizing antibody titres were low and could not be detected on some days. A similar response was observed with monovalent live attenuated AHSV 6 vaccine. Following processing of the serum samples for the neutralization assay, some samples displayed toxicity (T) towards the cells in this assay.

\section{Discussion}

In this study we describe the transient expression of the four major structural capsid proteins of AHSV in Nicotiana benthamiana $\mathrm{dXT} / \mathrm{FT}$ plants and their selfassembly into homogenous and chimeric virus-like particles (VLPs). Not only were we successful in demonstrating assembly of homogenous VLPs of AHSV serotype 1, 


\section{Protein view: ABI96882}

\section{Name: Major outer capsid protein VP2}

\section{Database: NCBI}

Score: 2184

Taxonomy: African Horse Sickness virus 6

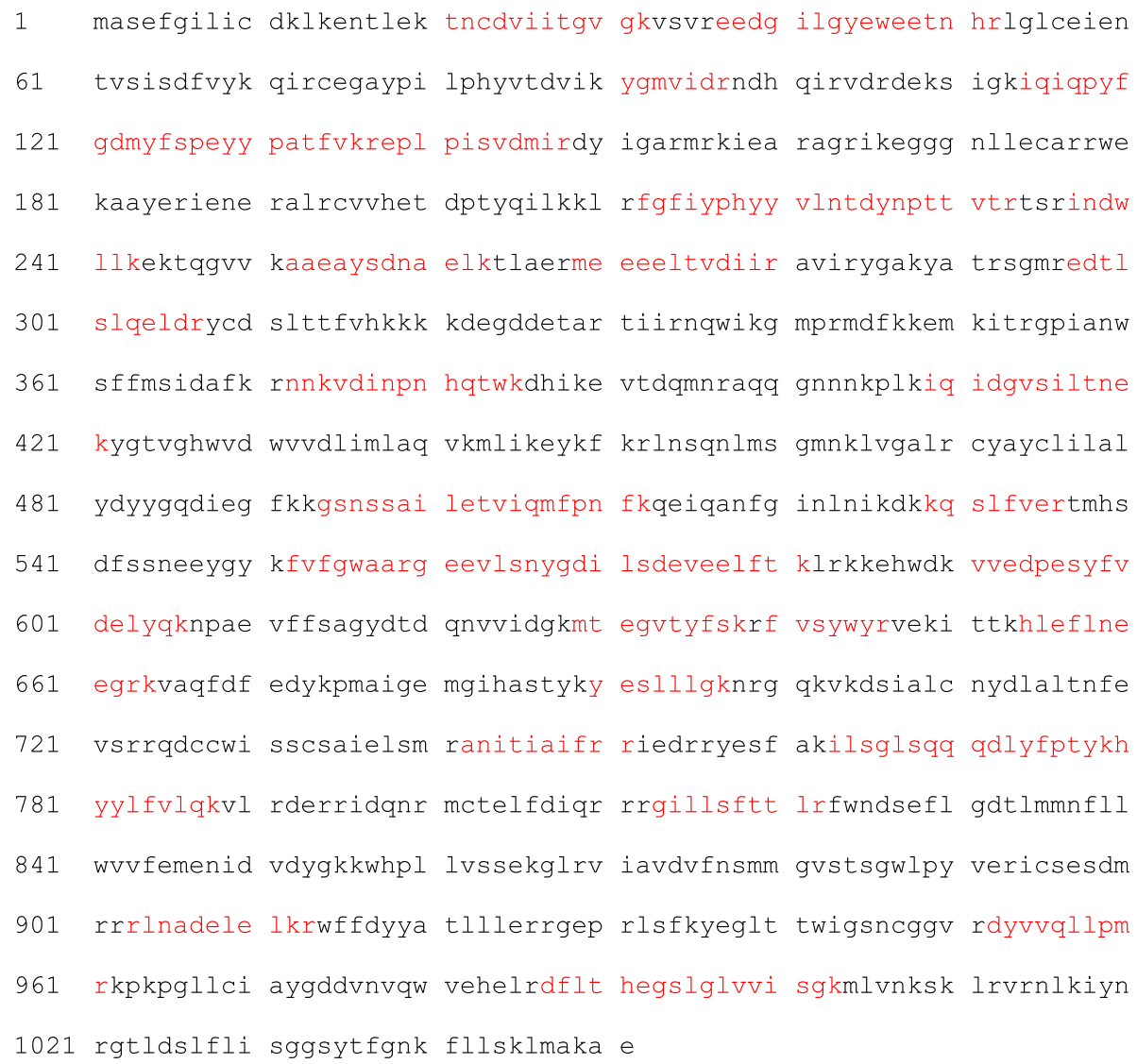

Fig. 5 LC-MS/MS based peptide sequencing analysis of putative VP2 protein bands excised from an SDS-PAGE gel. N.benthamiana leaves, coinfiltrated with constructs encoding the AHSV-6 VP2, AHSV-3 VP5, AHSV-1 VP3 and AHSV-1 VP7 proteins, were harvested and the extracted cell lysate centrifuged through a density gradient. Selected gradient fractions were electrophorized on an SDS-PAGE gel and the putative gel bands excised for MS analysis. Matched peptides are shown in red. Scores $>75$ are considered significant $(p<0.05)$

but also assembly of single, double and triple chimeric AHS VLPs, composed of a combination of capsid proteins from at least two different AHS serotypes. Transient expression of heterologous proteins in plants has a number of advantages over other expression platforms including speed, scalability, cost-effectiveness and safety $[34,38,53]$. It is thus not surprising that VLPs against a large number of diseases are currently being developed and produced in plants $[35,36]$. Self-assembly of BTV
VLPs in N. benthamiana plant cells following transient co-expression of the four BTV capsid proteins [42], prompted us to investigate whether this was also possible in the case of the closely related AHSV. Very recently the assembly of homogenous AHSV-5 VLPs was demonstrated in plants and found to elicit a neutralizing immune response in horses [44, 45]. Some promising preliminary work in our laboratory with an RNAi mutant $\mathrm{dXT} / \mathrm{FT} \quad N$. benthamiana, which facilitates 
Table 1 Virus neutralizing antibody titres of serum from adjuvanted AHSV-6 VLP and LAV (OBP) vaccinated horses ${ }^{a}$

\begin{tabular}{|c|c|c|c|c|c|c|c|c|}
\hline & Horse ID & Day 0 & Day 7 & Day 14 & Day 21 & Day 28 & Day 35 & Day 42 \\
\hline \multirow[t]{3}{*}{ AHSV-6 VLP vaccine } & $\# 2$ & 0 & $1: 2$ & $1: 2$ & $1: 4$ & $1: 4$ & $1: 4$ & $1: 8$ \\
\hline & $\# 3$ & 0 & 0 & $1: 32$ & $1: 16$ & $1: 8$ & $1: 16$ & $1: 32$ \\
\hline & $\# 6$ & 0 & $\mathrm{~T}$ & T & $1: 4$ & $\mathrm{~T}$ & $1: 2$ & $1: 4$ \\
\hline \multirow[t]{3}{*}{ AHSV-6 LAV (OBP) } & \#9 & 0 & 0 & $1: 4$ & $1: 4$ & $1: 4$ & $1: 4$ & $1: 2$ \\
\hline & $\# 10$ & 0 & $1: 2$ & $1: 4$ & $1: 8$ & $1: 4$ & $1: 16$ & $1: 8$ \\
\hline & $\# 11$ & 0 & $1: 8$ & $1: 8$ & $1: 4$ & $1: 8$ & $1: 4$ & $1: 4$ \\
\hline Bicine buffer (negative control) & $\# 14$ & 0 & $1: 2$ & 0 & $1: 2$ & 0 & 0 & 0 \\
\hline
\end{tabular}

a Sera were assayed for neutralization activity against AHSV-6. The adjuvant was Montanide ${ }^{\mathrm{TM}}$ Pet Gel A (Seppic)

T: Toxicity

mammalian-like glycosylation [46], and may result in AHSV VLPs more closely resembling AHSV virions with authentic post translational modifications, resulted in the use of this $\mathrm{dXT} / \mathrm{FT}$ as the expression host in this study.

We firstly wanted to determine whether we could demonstrate assembly of homogenous AHSV-1 VLPs in $N$. benthamiana $\mathrm{dXT} / \mathrm{FT}$ plants. To this end the four AHSV-1 capsid proteins, VP2, VP5, VP3 and VP7, were co-expressed in the plant cells and we were able to visualise homogenous AHSV-1 VLPs, approximately $70 \mathrm{~nm}$ in size $[1,2]$. AHSV-1 core-like particles (CLPs), approximately $60 \mathrm{~nm}$ in size and with a knob-like surface appearance were also visualised. The diameters of plantexpressed BTV VLPs have been reported to range from 72 to $86.8 \mathrm{~nm}$ whilst the BTV CLPs range from 60 to 69 $\mathrm{nm}$ in diameter $[42,43]$.

As AHS has 9 serotypes, it would be necessary to assemble VLPs of all nine serotypes and combine them into a multivalent vaccine in order to protect horses against the disease. With this in mind, we synthesized and transiently co-expressed plant-codon optimised sequences encoding the four capsid proteins of AHS serotype 7 in $N$. benthamiana dXT/FT plant cells. AHSV serotype 7 is one of the serotypes responsible for the majority of the AHS outbreaks between 1997 and 2006 [54]. Interestingly, we found that the serotype 7 capsid proteins, when co-expressed in plants, failed to assemble into AHSV-7 VLPs. This is not entirely unexpected as it has previously been shown that while the plantexpressed BTV-8 capsid proteins assemble into VLPs, the capsid proteins of the BTV-10 serotype fail to assemble [55].

We promptly embarked on a different strategy to generate AHSV-7 VLPs. As Orbiviruses are capable of genome segment reassortment, it is possible to exchange specific gene segments with those of another serotype and, through reverse genetics, generate 'chimeric'replication-deficient BTV and AHSV [49-52, 56]. It has also been shown that insect-cell expressed VP2 and VP5 outer capsid proteins of one BTV serotype assembled into chimeric BTV VLPs with the VP3 and VP7 core proteins of another BTV serotype [47, 48]. Here we aimed to generate plant-expressed, chimeric VLP-based AHS vaccine candidates by exchanging the outer capsid proteins AHSV VP2 and/or VP5 with those of a different serotype whilst retaining the conserved AHSV inner core (VP7 and VP3 proteins) of the original serotype. This strategy of generating 'chimeric' AHSV VLPs would reduce the number of constructs required and significantly simplify the process of generating a multivalent AHSV vaccine, composed of all nine AHSV serotypes.

We exchanged the AHSV-1 VP2 outer capsid protein, the main neutralizing antigen, with that of AHSV-7 VP2 protein, whilst retaining the VP3, VP7 and VP5 proteins of AHSV-1. We found that these capsid proteins assembled into single chimeric AHSV-1/AHSV-7 VLPs in $N$. benthamiana $\mathrm{dXT} / \mathrm{FT}$ plants. In an attempt to increase particle stability of the single chimeric AHSV-1/AHSV-7 VLPs, we also exchanged the AHSV-1 VP5 protein with that of the AHSV-7 serotype. Studies have shown that the VP5 outer capsid protein enhances the conformation of VP2, thus increasing this protein's interaction with core-like particles [57-59]. More recently, studies [51, 52] have shown that the exchange of only the VP2 segment can significantly lower the viral titre of reassortant viruses. We subsequently co-expressed the VP2 and VP5 proteins of AHSV-7 with the AHSV-1 VP3 and VP7 proteins in $N$. benthamiana $\mathrm{dXT} / \mathrm{FT}$ cells. We found that the quantity of VP2 and VP5 outer capsid proteins on the double AHSV-1/AHSV-7 chimeric VLPs was greater than their quantity on the single chimeric VLPs, as deduced by the intensity of the relevant protein bands, which indicated greater stability of the double chimeric VLP. Increased stability and replicative capability of some of the Entry competent replication abortive (ECRA) AHSV serotypes was also observed following the exchange of both the VP2 and VP5 proteins, but not in all serotypes [52]. Our research also indicated that the exchange of both the VP2 and VP5 proteins originating from the same serotype does not always allow for the formation of stable VLPs. Empirical studies of the 
different combinations of outer capsid proteins originating from the 9 AHSV serotypes were required to determine which yielded stable, serotype-specific VLPs. The use of the double recombinant $\mathrm{pEAQ}$-express vector, with the combined AHSV-1 VP7 and VP3 expression cassettes, greatly aided in facilitating these stability studies.

We report here on one of these combinations that resulted in the assembly of stable triple chimeric AHSV-6/ AHSV-3/AHSV-1 VLPs in $N$. benthamiana dXT/FT plants. In order to generate sufficient quantities of VLPs for animal trials, a large scale VLP purification procedure was optimised, which included depth filtration, tangential flow filtration (TFF), density gradient centrifugation and dialysis [60]. A target animal trial was conducted to determine whether these AHSV-6/AHSV3/AHSV-1 VLPs were able to induce a serotype-specific neutralizing antibody response in horses. The plantproduced, purified VLP inoculum was mixed with Montanide $^{\mathrm{Tm}}$ Pet Gel A (Seppic), identified as being a suitable adjuvant for horses [61]. Seven 6-month old foals were tested for the presence of AHSV VP7-specific antibodies via ELISA and were found to be AHSV naïve, not harbouring AHSV virus from either vaccination or infection. The ELISA test, a VP7-based assay, is capable of detecting the presence of all nine AHSV serotypes. We thus employed the serogroup-specific ELISA test instead of the serotype-specific serum neutralization test (SNT) to ensure no previous exposure of the foals to any of the AHS serotypes.

Primary and booster vaccinations were administered 28 days apart. The AHSV- 6 monovalent live attenuated vaccine (LAV) served as the positive control in three horses and while bicine buffer served as the negative control in one horse. No side effects or disease clinical signs were observed following inoculation of three horses with either the VLP-based or LAV vaccine. In addition, no lesions were observed at the site of injection suggesting the plant produced, VLP-based vaccine is safe for use in horses.

Weak neutralizing antibody titres against AHSV-6 were observed in horses inoculated with both the VLP and LAV vaccines. On some days antibodies were not even detected. Variability in immune responses of the individual foals to vaccination with both these vaccines was also observed. These results are not unexpected as previous studies have shown that young foals vaccinated with the commercial polyvalent, as well as monovalent AHSV vaccines, have weak or non-detectable and variable antibody responses to all AHSV serotypes, except serotype 1, and some only seroconvert after revaccination [62]. Current OBP AHS LAV protocol recommends 2 to 3 vaccinations to obtain sufficient titres of antibodies to confer protection against all serotypes in the vaccine and a recent study [63] suggests up to eight vaccinations before full protection can be conferred. It is likely that, as with the live attenuated polyvalent vaccine, multiple vaccinations with the AHSV VLPs will be required to induce titres of neutralizing antibodies sufficient for protection. Low inconsistent reactions obtained with the negative control in this study was attributed to the presence of passively acquired, maternal neutralizing antibody in the six-month old foal. The duration of maternal antibodies against AHSV-6 has previously been found to be 115 days (3.8 months) [64], however, the small sample size $(n=6)$ may result in this period not being indicative of the actual duration. As seroconversion is considered positive when the neutralizing antibodies are at titres of 4 or higher, and no VP7-specific antibodies were detected with ELISA, negative control foal \#14 is considered seronegative. In future studies we would like to increase the sample size as well as use AHSV-naïve horses that are older than 12 months in order to reduce the effect of maternal antibodies on the results.

This is the first report of plant-produced, chimeric AHSV VLPs vaccines eliciting a neutralizing immune response in horses. Chimeric VLPs are defined as having their component structural proteins originating from at least two different serotypes. Here we have shown that, not only do chimeric VLPs assemble successfully in $N$. benthamiana dXT/FT plants, but they are also able to elicit a serotype-specific immune response in the target animal. This is the first step in the development of a plant-produced, multivalent AHS vaccine, formulated with a combination of homogenous and chimeric VLPs, and capable of inducing species-specific immunity against all nine AHS serotypes.

\section{Conclusions}

In the present study we report on the development of a novel virus-like particle (VLP)-based vaccine, produced in plants, to be used as a preventative measure against African horse sickness disease in horses. We demonstrate that chimeric VLPs, composed of proteins from different AHSV serotypes and produced in plants, are capable of inducing serotype-specific neutralizing antibodies when injected into horses. This new generation vaccine may be utilized as a safe alternative to the current live attenuated vaccine in a control strategy against this devastating, OIE notifiable disease.

\section{Methods}

\section{Constructs}

Gene sequences, encoding the VP2, VP5, VP3 and VP7 proteins of AHSV serotype 1 (Genbank accession numbers AM883165, FJ183369, FJ183366, AM883171, respectively), the VP2 (Genbank accession number 
AY163330) and VP5 (Genbank accession number JQ742011) proteins of AHSV serotype 7, the VP5 protein of AHSV serotype 3 (Genbank accession number DQ868777 and the VP2 protein of AHSV serotype 6 (Genbank accession number DQ868774.1) were codon optimised for optimal expression in $N$. benthamiana plant cells and synthesized with AgeI and XhoI sites at the $5^{\prime}$ and $3^{\prime}$ termini, respectively (BioBasic Inc., Canada).

The VP2, VP5, VP3 and VP7-encoding nucleotide sequences were subsequently cloned into the pEAQ transient expression vectors [40], made available to the CSIR under a licence agreement from Plant Bioscience Limited (PBL), UK. More specifically, sequences encoding the AHSV-1 VP2, VP5, VP3 and VP7 proteins were firstly cloned into the intermediate $\mathrm{pEAQ}$ vectors FSC5 or FSC6 via directional AgeI/XhoI restriction enzymebased cloning. The AHSV-1 VP5- and AHSV-1 VP7encoding expression cassettes were subsequently individually cloned into the $\mathrm{pEAQ}$ express vector via directional AscI/SbfI restriction enzyme-based cloning. The AHSV-1 VP2 and VP3-encoding genes were inserted into the pEAQ-HT vector individually via directional AgeI/XhoI restriction enzyme-based cloning. The AHSV-7 VP2 and AHSV-7 VP5 encoding sequences were cloned individually into the $\mathrm{pEAQ}-\mathrm{HT}$ vector via directional AgeI/XhoI restriction enzyme-based cloning. Cloning of the sequences encoding the AHSV-3 VP5 and AHSV-6 VP2 proteins individually into the pEAQ$\mathrm{HT}$ vector was performed using the In-Fusion $\mathrm{HD}^{\circ}$ cloning kit (Clontech), according to the manufacturer's instructions.

To generate the dual recombinant plasmid pEAQexpress-AHSV-1VP3-AHSV-1VP7, the AHSV-1 VP7 encoding sequence was firstly cloned from the $\mathrm{pEAQ}$ express-AHSV-1VP7 plasmid into the pEAQ-HT vector via directional AgeI/XhoI restriction enzyme-based cloning. The VP7-encoding expression cassette was subsequently excised from pEAQ-HT-AHSV-1VP7 using the AscI/PacI enzymes and cloned into the compatible MluI/AsiSI sites of the pEAQ-express vector. The VP3encoding expression cassette was transferred from the pEAQ-HT-AHSV-1VP3 plasmid into the newly generated $\mathrm{pEAQ}$-express-AHSV-1VP7 plasmid via AscI/PacI mediated restriction enzyme based cloning. Recombinant plasmids were transformed into electrocompetent Escherichia coli DH10B bacterial cells and their sequences verified via dideoxy Sanger DNA sequencing (Inqaba Biotechnical Industries (Pty) Ltd).

\section{Agrobacterium-mediated infiltration of Nicotiana benthamiana plants}

All expression constructs were transformed into Agrobacterium tumefaciens LBA4404 bacterial cells
(Invitrogen) by electroporation and propagated at $28^{\circ} \mathrm{C}$ in YMB media $(0.1 \%$ yeast extract, $1 \%$ Mannitol, $1.7 \mathrm{mM}$ $\mathrm{NaCl}, 0.8 \mathrm{mM} \mathrm{MgSO} \mathrm{O}_{4} \cdot \mathrm{H}_{2} \mathrm{O}, 2.2 \mathrm{mM} \mathrm{K} \mathrm{HPO}_{4}$ ) containing $50 \mu \mathrm{g} / \mathrm{ml}$ Kanamycin, $50 \mu \mathrm{g} / \mathrm{ml}$ Rifampicin and $50 \mu \mathrm{g} / \mathrm{ml}$ Streptomycin. Cryopreserved LBA4404 cells, containing the pEAQ-HT vector or the pEAQ-HT-GFP recombinant plasmid (G. Lommonosoff, John Inness Centre, UK), served as negative and positive controls, respectively. Seeds of the N. benthamiana dXT/FT plants were originally acquired from Icon Genetics $\mathrm{GmbH}$ under the auspices of a Material transfer agreement. Transient expression of the AHSV capsid proteins in N. benthamiana $\mathrm{dXT} / \mathrm{FT}$ plants was accomplished by Agrobacterium-mediated infiltration of their leaves.

LBA4404 agrobacterial cultures grown overnight were harvested via centrifugation $\left(7000 \times \mathrm{g}\right.$ for $7 \mathrm{~min}$ at $\left.10^{\circ} \mathrm{C}\right)$ and pellets resuspended in freshly prepared MMA infiltration buffer (10 mM MES hydrate; pH 5.6, $10 \mathrm{mM}$ $\mathrm{MgCl}_{2}, 100 \mu \mathrm{M}$ 3, 5-Dimethoxy-4-hydroxy-acetophenone). The bacterial suspensions were combined in 1:1:1 ratios for VLP assembly while the pEAQ-express-AHSV1VP7-AHSV-1VP3 suspension was sufficient for CLP assembly. The combinations were subsequently diluted with MMA buffer such that the final $\mathrm{OD}_{600}=0.45-0.5$ or, in the case of plants being infiltrated for animal trials, an $\mathrm{OD}_{600}=2$. The leaves of four-week-old N. benthamiana $\mathrm{dXT} / \mathrm{FT}$ plants were syringe-infiltrated with the bacterial combinations or the pEAQ-HT/pEAQ-HT-gfp bacterial suspensions. The plants were incubated at $27^{\circ} \mathrm{C}$.

\section{Protein extraction and small scale VLP purification}

Agroinfiltrated $N$. benthamiana leaves were harvested 8 days post-infiltration (d.p.i). The leaf tissue was extracted immediately in 3 volumes of VLP extraction buffer $(50 \mathrm{mM}$ Bicine, $\mathrm{pH}=8.4,20 \mathrm{mM}$ sodium chloride $(\mathrm{NaCl}), 0.1 \%(\mathrm{w} / \mathrm{v})$ Sodium lauroyl sarcosine (NLS), 1 mM Dithiothreitol (DTT) (ThermoScientific), 0.2\% Protease inhibitor cocktail P2714 (Sigma Life Science)) in a multipurpose juice extractor (MATSONE). The DTT and Protease inhibitor cocktail were freshly prepared according to the manufacturer's instructions and added to the extraction buffer just prior to use. The plant extract was clarified via centrifugation $\left(8000 \times \mathrm{g} ; 10 \mathrm{~min} ; 4^{\circ} \mathrm{C}\right)$.

AHS virus-like particles (VLPs) or core-like particles (CLPs) were purified using density gradient centrifugation using either sucrose or iodixanol density media. Sucrose gradient solutions $(60-30 \%)$ were prepared by dissolving ultra-high quality sucrose (Sigma Life Science) in VLP buffer $(50 \mathrm{mM}$ Bicine, $\mathrm{pH}=8.4,20 \mathrm{mM} \mathrm{NaCl}$ ) and layered into gradients of $1 \mathrm{ml} \mathrm{10 \%} \mathrm{incremental} \mathrm{steps.}$ Iodixanol solutions $(60-20 \%)$ were prepared by diluting 60\% iodixanol (OptiPrep ${ }^{\text {Tw }}$ Density Gradient Medium) (Sigma-Aldrich) in VLP dilution buffer and layered into 
gradients of $10 \%$ incremental steps. The clarified cell lysates were layered on top of the sucrose gradients and centrifuged in a SW-41Ti rotor (Beckman Coulter) at $32,000 \times \mathrm{g}$ for $2 \mathrm{~h} ; 10^{\circ} \mathrm{C}$. The $55-35 \%$ sucrose layers, or $35-25 \%$ iodixanol layers, were harvested in $500 \mu \mathrm{l}$ fractions via a Minipuls2 peristaltic pump (Gilson). Ten microlitres of each fraction was subsequently analysed for protein content by denaturing 10\% SDS-PAGE (BioRad TGX Stain Free ${ }^{\mathrm{Tm}}$ Fast Cast $\left.{ }^{\mathrm{Tm}}\right)$, according to the manufacturer's instructions. The Precision Plus Protein ${ }^{\mathrm{nt}}$ Western $\mathrm{C}^{\mathrm{m}}$ standard (Bio-Rad) or the PageRuler Plus Prestained protein ladder (Thermo Scientific) were used as size markers. The gels were either subjected to $0.1 \%$ Coomassie Brilliant Blue G250 staining (Merck) and subsequent destaining, or to immunoblotting procedures with a guinea pig anti-AHSV-7 polyclonal serum (kindly donated by Onderstepoort Biological Products (OBP)). Protein samples were immunoblotted onto a PVDF membrane within the Trans-blot ${ }^{\oplus}$ Turbo $^{\text {TM }}$ Transfer Pack (Bio-Rad) using the Trans-Blot ${ }^{\circ}$ Turbo $^{\text {ru }}$ Transfer system (Bio-Rad) mixed MW application, according to the manufacturer's instructions. The membranes were blocked and incubated with the polyclonal antiserum (1:300 dilution in 3\% Bovine serum albumin (Roche)) overnight at $4{ }^{\circ} \mathrm{C}$. Following washing Rabbit anti-Guinea Pig IgG H\&L (HRP) conjugate (Abcam ab6771) (1:5000 dilution) and Precision Protein ${ }^{\text {TM }}$ StrepTactin-HRP Conjugate (Bio-Rad) (1:10000 dilution) secondary antibodies were incubated with the membrane for $1 \mathrm{~h}$ at room temperature. Clarity Western ECL chemiluminescent substrate (Bio-Rad), according to the manufacturer's instruction, was added to detect the proteins and imaging was performed using the Chemi Hi Resolution application in the ChemiDoc ${ }^{\text {Tw }}$ MP Imager (Bio-Rad).

\section{Protein confirmation using LC-MS/MS-based peptide sequencing}

Following electrophoresis of density gradient fraction samples on precast denaturing $4-12 \%$ Bolt $^{\mathrm{Tu}}$ Bis-Tris Plus polyacrylamide Gels (Thermo Fischer Scientific), according to the manufacturer's instructions, and Coomassie Brilliant Blue G250 staining and destaining, candidate protein bands of approximately the correct size were excised from the gel and sent for LCMS-MS peptide sequencing analysis, previously described by our colleagues [65]. Briefly, the protein bands were in-gel trypsin digested, resuspended in $2 \%$ acetonitrile $/ 0.2 \%$ formic acid and analysed using a Dionex Ultimate 3000 RSLC system coupled to an AB Sciex 6600 Triple TOF mass spectrometer. The obtained MS/MS spectra were compared with the Uniprot Swissprot protein database by using Protein pilot v5, which makes use of the Paragon search engine (AB Sciex). Proteins with a threshold above $\geq 99.9 \%$ confidence were reported.

\section{Transmission electron microscopy (TEM)}

VLPs from the 55-45\% sucrose fractions were visualised by adsorbing samples onto carbon-coated holey copper grids $(5 \mathrm{~min})$ and subsequently stained with $2 \%$ sodium phosphotungstate, $\mathrm{pH}=7$ for $30 \mathrm{~s}$. The grids were air dried and subsequently imaged in a JEM-2100 Transmission electron microscope (JEOL). VLPs from 35 to $25 \%$ iodixanol fractions were visualised by adsorbing samples onto carbon-coated holey copper grids $(5 \mathrm{~min})$ and stained with $3 \%$ uranyl acetate, $\mathrm{pH}=4.2$ for $20 \mathrm{~s}$. Grids were air dried and imaged in a CM-10 Transmission electron microscope (Philips). The diameters of the particles visualised on the grid were measured using the measure tool on the Gatan Digital Micrograph software. Thirty five particles of each type were measured and the mean diameter calculated.

\section{Large scale AHSV VLP purification for animal trials}

Leaves of $N$. benthamiana dXT/FT plants were infiltrated with the appropriate recombinant Agrobacteria combinations, as detailed previously (7.2), and plants incubated at $27^{\circ} \mathrm{C}$. Infiltrated leaves were harvested 8 d.p.i, weighed and processed through a juice extractor (MATSONE) with 2 volumes of VLP buffer $(20 \mathrm{mM} \mathrm{NaCl}, 50$ $\mathrm{mM}$ Bicine, $\mathrm{pH}=8.4$ ). Protease Inhibitor cocktail P2714 (Sigma Life Science) was added to the buffer immediately prior to use, according to the manufacturer's instructions. The cell extract clarified via centrifugation $\left(8000 \times \mathrm{g} ; 10 \mathrm{~min} ; 4^{\circ} \mathrm{C}\right)$ and filtered through a Sartoclean GF sterile midicap $(3+0.8 \mu \mathrm{M})$ depth filter (Sartorius Stedim Biotech $\mathrm{GmbH}$ ) and subsequently a $300 \mathrm{~K}$ Minimate $^{\mathrm{Tm}}$ Tangential Flow Filtration (TFF) Capsule (Pall Life Sciences) until the extract was reduced to one tenth of its original volume. Following centrifugation through 60-20\% Iodixanol density gradients $(32,000 \times \mathrm{g} ; 2 \mathrm{~h}$; $10{ }^{\circ} \mathrm{C}$ ), the $35-25 \%$ iodixanol fractions were combined and dialysed against sterile buffer $(20 \mathrm{mM} \mathrm{NaCl}, 50 \mathrm{mM}$ Bicine, $\mathrm{pH}=8.4$ ) overnight in SnakeSkin ${ }^{\mathrm{Tw}}$ dialysis tubing (Thermo Fischer Scientific). The sample was filtersterilized through a $0.45 \mu \mathrm{M}+0.2 \mu \mathrm{M}$ Sartobran 300 Sterile capsule (Sartorius Stedim Biotech $\mathrm{GmbH}$ ) and 5 $\%$ Montanide $^{\mathrm{Tu}}$ Pet Gel A (Seppic) was added as an adjuvant. Samples were stored at $4{ }^{\circ} \mathrm{C}$ prior to use in the animal trial. The protein content of the filter-sterilized sample was quantified by using the Micro $\mathrm{BCA}^{\mathrm{sx}}$ Protein Assay kit (Thermo Fisher Scientific), according to the manufacturer's instructions, Aliquots, taken throughout the course of the purification procedure, were analysed for protein content by iodixanol centrifugation and fraction analysis via denaturing SDS-PAGE. VLPs were visualised via TEM. The aliquot of the concentrated filter-sterilized sample was diluted 1 in 10 prior to centrifugation and TEM. 


\section{Animal care and animal facility}

Healthy horses (Equus caballus) of both sexes, between 6 and 12 months, were sourced from a farmer, tested for AHSV status via Enzyme-linked immunosorbent assay (ELISA) according to the protocol described in the Office International des Epizooties (OIE) Manual of Diagnostic Tests and Vaccines for Terrestrial Animals [66] and treated against any other ailments prior to the start of the trial. The animals were housed in closed stable 166 at OBP for the duration of the trial. Large animals were handled and cared for according to standard operating procedures outlined by the Experimental Animal Unit. Briefly, horses were fed Epol Riders pellets. Eragrostis and clean water ad lib. The horses were not euthanized and returned to the farmer upon completion of the animal trial on day 42 .

\section{Immunogenicity trial in horses}

Seven AHS-naïve foals were randomly allocated into one test, one positive control and one negative control group for the immunogenicity trial, stabled in closed stable 166 at OBP and handled according to regulatory guidelines and standard operating procedures outlined by the Experimental Unit. The welfare of the horses was monitored daily by competent staff according to a standard welfare monitoring sheet, with instructions to report any adverse effects immediately to the project leader. The inoculation site (subcutaneous route) was monitored for recordings of local reactions (onset and duration) and body temperatures recorded for a minimum of 3 days before vaccination and for 14 days post vaccination. Vaccination and bleeding of animals was according to standard operating protocols by trained and competent staff and done in the morning in the closed stables. Bleeding via venepuncture was performed with 19 gauge needles in $10 \mathrm{ml}$ yellow vacutubes (Labchem Sdn Bhd) and sent the same day for laboratory analysis. The presence of AHSV VP7-specific antibodies in the foals was assayed by an Indirect Enzyme-linked immunosorbent assay (ELISA), performed by ARC-OVR according to the protocol described in the Office International des Epizooties (OIE) Manual of Diagnostic Tests and Vaccines for Terrestrial Animals [66]. The statistical requirement for the minimum number of animals per group was 8 and this number is also required for vaccine data registration. However, previous experimental research using a reduced number of animals has shown 3 animals are sufficient to achieve the required scientific objectives $[68,69]$.

In order to obtain preliminary data for this proof of concept study, three foals were injected subcutaneously into the inner thigh with sterile Montanide ${ }^{\text {ma }}$ Pet Gel A adjuvanted AHSV-1/AHSV-3/AHSV-6 VLPs (final volume of $2 \mathrm{ml}$ containing $220 \mu \mathrm{g}$ of total protein) on Day
0 . Two hundred microgram total protein has previously been used to vaccinate horses against homogenous AHSV-5 VLPs [45]. One foal was inoculated subcutaneously into the inner thigh with sterile Montanide ${ }^{\text {rm }}$ Pet Gel A adjuvanted bicine buffer as a negative control. Three horses were inoculated with 1x10E4 per dose monovalent AHSV-6 live attenuated vaccine subcutaneously into the inner thigh as a positive control. Subcutaneous administration of the live attenuated AHSV vaccine is routine and this same route was used for the administration of the VLP-based antigen. The animals were boosted using the same route of administration and same antigen dose on day 28 of the immunization schedule and serum samples taken on days $0,7,14,21$, 28, 35 and 42. The presence of neutralizing antibodies in each experimental animal was determined by performing a virus neutralization assay on homologous AHSV-6 monovalent viral strain [67]. This assay was performed by OBP according to the protocol described in the OIE Manual of Diagnostic Tests and Vaccines for Terrestrial Animals [66]. The 50\% end-point titre of the serum is calculated by the Spearman-Kärber method and expressed as the negative $\log _{10}$.

\section{Abbreviations}

AHS: African horse sickness; AHSV: African horse sickness virus; ARCOVR: Agricultural Research council-Onderstepoort Veterinary Research; BT: Bluetongue; BTV: Bluetongue virus; CLP: Core-like particle; CSIR: Council for Scientific and Industrial Research; d.p.i: days post infiltration;

DAFF: Department of agriculture, forestry and fisheries; DIVA: Differentiation between infected and vaccinated animals; DTT: Dithiothreitol;

E.coli: Escherichia coli; ELISA: Enzyme-linked immunosorbent assay; gfp: green fluorescent protein; HRP: Horse radish peroxidase; LAV: Live attenuated virus; LC-MS/MS: Liquid chromatography-mass spectrometry; OBP: Onderstepoort Biological Products; OIE: World organisation for animal health; PBL: Plant Bioscience Limited; SDS-PAGE: Sodium dodecyl sulphate polyacrylamide gel electrophoresis; TEM: Transmission electron microscope; TFF: Tangential flow filtration; UK; RNAi: RNA interference; VLP: Virus-like particle; VP3/7/5/2: Viral protein $3 / 7 / 5 / 2$

\section{Acknowledgements}

The authors would like to thank Professor George Lomonossoff (John Innes Centre, Norwich, UK) for providing the pEAQ-HT and pEAQ-express vectors (under licence from Plant Biosciences Ltd. (LTD). Icon Genetics GmbH for providing the seeds of the $N$. benthamiana $\mathrm{dXT} / \mathrm{FT}$ plants under the auspices of a Material Transfer agreement. Mr. Albert Mabetha (CSIR) for ensuring an adequate supply of N.benthamiana plants. Drs Ereck Chakauya and Rachel Chikwamba for establishing the plant-based expression platform at the CSIR. Mr. Sipho Mamputha and Dr. Stoyan Stoychev (CSIR) for conducting the LCMS/MS-based peptide sequencing. Ms. Antoinette Lensink at the Laboratory for Microscopy and Microanalysis, University of Pretoria, Onderstepoort campus for conducting performing the TEM work. Members of Experimental Animal Department at Onderstepoort biological products (OBP) for animal handling and conducting the target animal trial. Researchers at OBP and ARC-OVR for conducting AHSV VP7-specific ELISA assays and AHSV neutralization assays, respectively.

\section{Authors' contributions}

DAR and NBM drafted the manuscript. DAR selected the genes, cloned them into the appropriate plant expression vectors and produced AHSV VLPS in plants. MMOK suggested alignments between the different AHSV serotypes to determine which chimeric protein combinations should be tested. DAR aligned protein sequences and validated the various chimeric VLP protein combinations in plants. TLT guided the larger scale filtration and 
ultrafiltration procedures. DAR, MMOK and TLT prepared the primary and booster VLP vaccines. DAR and MMOK participated in the vaccine formulation and NBM designed the animal trial study. NBM and VSD conducted the animal trials and conducted assays. All authors read and approved the final manuscript.

\section{Funding}

A number of grants contributed towards the funding of this study. This included the Technology and Innovation Agency Grant \#TAHC12 00013 as well as complementary funding from both the CSIR and OBP. National research foundation's (NRF) Professional Development Programme (PDP) and Young Researcher Establishment Funding (YREF) supported DAR. CSIR, OBP, NRF, PDP, YREF and the Technology and Innovation Agency had no role in the design of the study and collection, analysis and interpretation of data and in writing the manuscript.

\section{Availability of data and materials}

The datasets used and/or analysed during the current study are available from the corresponding author on reasonable request.

\section{Ethics approval}

The CSIR Biosciences has DAFF-registered laboratory, growth rooms and pilot plant facilities (Registration number 39.2/CSIR - 17/099 from 13 November 2017 until 13 November 2020) to produce the vaccine antigens in plants. Approval for the immunization of horses in this study was obtained from the council for scientific and industrial research (CSIR) research ethics committee (Reference \#199/2016) and the Onderstepoort biological products (OBP) animal ethics committee (Reference \#2015/003C). Permission to conduct the study in terms of Section 20 of the Animal Diseases Act 1984 (ACT NO. 35 of 1984) was obtained from the South African Department of Agriculture, Forestry and Fisheries (DAFF Reference \#12/11/1/1). Written informed consent was obtained from the farmer, the owner of the animals, to use his horses in this study. All animals in this research project received humane and compassionate treatment and were housed, handled, utilized and generally treated in terms of existing and relevant national legislation and codes of practice including:

- Animal Protection Act 71/1962

- Medicines and Related Substance Control Act 101/1982

- Veterinary and Para- Veterinary Professions Act 19/1982

- Fertilizers, farm feed, agricultural remedies and stock remedies Act 36/ 1947

- National Code for Animal Use in Research, Education, Diagnosis and Testing of Drugs and Related Substances in SA.

- SANS 10386:2008 The care and use of animals for scientific purposes

\section{Consent for publication}

Not applicable.

\section{Competing interests}

DAR, NBM and MMOK have filed a patent application protecting the production of chimeric Orbivirus virus-like particles in plants (PCT/IB2017/ 052236).

\section{Author details}

${ }^{1}$ CSIR Chemicals, PO Box 395, Pretoria 0001, South Africa. ${ }^{2}$ Onderstepoort Biological Products SOC Ltd, Private Bag X07, Onderstepoort 0110, South Africa.

Received: 6 June 2019 Accepted: 20 November 2019

Published online: 03 December 2019

\section{References}

1. Coetzer JAW, Guthrie AJ. African horse sickness. In: Coetzer JAW, Tustin RC, editors. Infectious Diseases of Livestock. 2nd ed. Oxford University Press Southern Africa: Cape Town; 2004. p. 1231-46.

2. Mellor PS, Hamblin C. African horse sickness. Vet Res. 2004;35:445-66.

3. De Vos CJ, Hoek CA, Nodelijk G. Risk of introducing African horse sickness virus into the Netherlands by international equine movements. Prev Vet Med. 2012;106:108-22.
4. Venter GJ, Graham SD, Hamblin C. African horse sickness epidemiology: Vector competence of South African Culicoides species for virus serotypes 3, 5 and 8. Med Vet Entomol. 2000;14:245-50.

5. Manole V, Laurinmaki P, Van Wyngaardt W, Potgieter CA, Wright IM, Venter GJ, van Dijk AA, Sewell T, Butcher SJ. Structural Insight into African horsesickness virus infection. J Virol. 2012;86:7858-66.

6. Mertens PP, Diprose J. The bluetongue virus core: a nano-scale transcription machine. Virus Res. 2004;101(1):29-43.

7. Burrage TG, Trevejo R, Stone-Marschat M, Laegreid WW. Neutralizing epitopes of African horsesickness virus serotype 4 are located on VP2. Virology. 1993;196:799-803.

8. Martinez-Torrecuadrada JL, Iwata H, Venteo A, Casal I, Roy P. Expression and characterisation of the two outer capsid proteins of African horsesickness virus: the role of VP2 in virus neutralization. Virology. 1994:202:348-59.

9. Martinez-Torrecuadrada JL, Diaz-Laviada M, Roy P, Sanchez C, Vela C, Sanchez Vizcaino JM, Casal JI. Full protection against African horsesickness (AHS) in horses induced by baculovirus-derived AHS virus serotype 4 VP2, VP5 and VP7. J Gen Virol. 1996;77:1211-21.

10. Roy P, Bishop DH, Howard S, Aitchison H, Erasmus B. Recombinant baculovirus synthesized African horse sickness virus (AHSV) outer-capsid protein VP2 provides protection against virulent AHSV challenge. J Gen Virol. 1996;77:2053-7.

11. Von Teichman BF, Dungu B, Smit TK. In vivo cross-protection to African horsesickness serotypes 5 and 9 after vaccination with Serotypes 8 and 6 . Vaccine. 2010;28:6505-17.

12. Weyer $C T$, Grewar JD, Burger $P$, Rossouw E, Lourens $C$, Joone C. African horse sickness caused by genome reassortment and reversion to virulence of live, attenuated vaccine viruses, South Africa, 2004-2014. Emerg Infect Dis. 2016;22:2087-96.

13. Grewar JD, Weyer $C T$, Venter $G J$, van Helden $L S$, Burger $P$, Guthrie AJ, Coetzee P, Labuschagne K, Buhrmann G, Parker BJ, Thompson PN. A field investigation of an African horse sickness outbreak in the controlled area of South Africa in 2016. Transbound Emerg Dis. 2018;66(2):743-51.

14. Scanlen M, Paweska JT, Verschoor JA, van Dijk AA. The protective efficacy of a recombinant VP2-based African horsesickness subunit vaccine candidate is determined by adjuvant. Vaccine. 2002;20:1079-88.

15. Kanai Y, van Rijn PA, Maris-Veldhuis M, Kaname Y, Athmaram TN, Roy P. Immunogenicity of recombinant VP2 proteins of all nine serotypes of African horse sickness virus. Vaccine. 2014;32:4932-7.

16. Guthrie AJ, Quan M, Lourens CW, Audonnet J-C, Minke JM, Yao J, He L, Nordgren R, Gardner IA, MacLachlan NJ. Protective immunization of horses with a recombinant canarypox virus vectored vaccine co-expressing genes encoding the outer capsid proteins of African horse sickness virus. Vaccine. 2009;27:4434-8.

17. El Garch H, Crafford JE, Amouyal P, Durand PY, Edlund Toulemonde C, Lemaitre L, Cozette V, Guthrie A, Minke JM. An African horse sickness virus serotype 4 recombinant canarypox virus vaccine elicits specific cellmediated immune responses in horses. Vet Immunol Immunopathol. 2012; 149:76-85.

18. Alberca B, Bachanek-Bankowska K, Cabana M, Calvo-Pinilla E, Viaplana E, Frost L, Gubbins S, Urniza A, Mertens P, Castillo-Olivares J. Vaccination of horses with a recombinant modified vaccinia Ankara virus (MVA) expressing African horse sickness 9 virus major capsid protein VP2 provides complete clinical protection against challenge. Vaccine. 2014;32:3670-4.

19. Manning NM, Bachanek-Bankowska K, Mertens PPC, Castillo-Olivares J. Vaccination with recombinant Modified Vaccinia Ankara (MVA) viruses expressing single African horse sickness virus VP2 antigens induced crossreactive virus neutralising antibodies (VNAb) in horses when administered in combination. Vaccine. 2017;35(44):6024-9.

20. Calvo-Pinilla E, Gubbins S, Mertens P, Ortego J, Castillo-Olivares J. The immunogenicity of recombinant vaccines based on modified Vaccinia Ankara (MVA) viruses expressing African horse sickness virus VP2 antigens depends on the levels of expressed VP2 protein delivered to the host. Antiviral Res. 2018;154:132-9.

21. Aksular M, Calvo-Pinilla E, Marín-López A, Ortego J, Chambers AC, King LA, Castillo-Olivares J. A single dose of African horse sickness virus (AHSV) VP2 based vaccines provides complete clinical protection in a mouse model. Vaccine. 2018;36(46):7003-10.

22. Vermaak E, Paterson DJ, Conradie A, Theron J. Directed genetic modification of African horse sickness virus by reverse genetics. S Afr J Sci. 2015;111:1-8. 
23. Van Rijn PA, van de Water SG, Feenstra F, van Gennip RG. Requirements and comparative analysis of reverse genetics for bluetongue virus (BTV) and African horse sickness virus (AHSV). Virol J. 2016;13:119.

24. Lulla V, Losada A, Lecollinet S, Kerviel A, Lilin T, Sailleau C, Beck C, Zientara S, Roy P. Protective efficacy of multivalent replication-abortive vaccine strains in horses against African horse sickness virus challenge. Vaccine. 2017; 35(33):4262-9.

25. Kushnir N, Streatfield SJ, Yusibov V. Virus-like particles as a highly efficient vaccine platform: diversity of targets and production systems and advances in clinical development. Vaccine. 2012;31:58-83.

26. Johnson JE, Chiu W. Structures of virus and virus-like particles. Curr Opin Struct Biol. 2000;10:229-35.

27. Jennings GT, Bachmann MF. The coming of age of virus-like particle vaccines. Biol Chem. 2008;389:521-36.

28. Grgacic EV, Anderson DA. Virus-like particles: passport to immune recognition. Methods. 2006;40(1):60-5.

29. Roy P, Bishop DH, LeBlois H, Erasmus BJ. Long-lasting protection of sheep against bluetongue challenge after vaccination with virus-like particles: evidence for homologous and partial heterologous protection. Vaccine. 1994;12:805-11.

30. Stewart M, Dubois E, Sailleau C, Breard E, Viarouge C, Desprat A, Thiery R, Zientara S, Roy P. Bluetongue virus serotype 8 virus-like particles protect sheep against virulent virus infection as a single or multi-serotype cocktail immunogen. Vaccine. 2013;31:553-8.

31. Maree S, Maree FF, Putterill JF, de Beer TAP, Huismans H, Theron J. Synthesis of empty African horse sickness virus particles. Virus Res. 2016;213:184-94.

32. Edgue G, Twyman RM, Beiss V, Fischer R, Sack M. Antibodies from plants for bionanomaterials. Wiley Interdiscip Rev Nanomed Nanobiotechnol. 2017. https://doi.org/10.1002/wnan.1462.

33. Brillault $L$, Jutras PV, Dashti N, Thuenemann EC, Morgan G, Lomonossoff GP, Landsberg MJ, Sainsbury F. Engineering recombinant virus-like nanoparticles from plants for cellular delivery. ACS Nano. 2017;11(4):3476-84.

34. Yusibov V, Streatfield SJ, Kushnir N. Clinical development of plant-produced recombinant pharmaceuticals: vaccines, antibodies and beyond. Hum Vaccin. 2011;7:313-21.

35. Rybicki EP. Plant-based vaccines against viruses. Virol J. 2014;11:205.

36. Marsian J, Lomonossoff GP. Molecular pharming-VLPs made in plants. Curr Opin Biotechnol. 2016:37:201-6.

37. Topp E, Irwin R, McAllister T, Lessard M, Joensuu JJ, Kolotilin I, Conrad U, Stöger E, Mor T, Warzecha H, Hall JC, MD ML, Cox E, Devriendt B, Potter A, Depicker A, Virdi V, Holbrook L, Doshi K, Dussault M, Friendship R, Yarosh O, Yoo HS, MacDonald J, Menassa R. The case for plant-made veterinary immunotherapeutics. Biotechnol Adv. 2016;34:597-604.

38. Buyel JF, Twyman RM, Fischer R. Very large scale production of antibodies in plants: The biologization of manufacturing. Biotechnol Adv. 2017;35(4): 458-65.

39. Steele JF, Peyret H, Saunders K, Castells-Graells R, Marsian J, Meshcheriakova Y, Lomonossoff GP. Synthetic plant virology for nanobiotechnology and nanomedicine. Wiley Interdiscip Rev Nanomed Nanobiotechnol. 2017;9: e1447.

40. Sainsbury F, Thuenemann EC, Lomonossoff GP. pEAQ: versatile expression vectors for easy and quick transient expression of heterologous proteins in plants. Plant Biotechnol J. 2009;7:682-93.

41. Peyret H, Lomonossoff GP. When plant virology met Agrobacterium: the rise of the deconstructed clones. Plant Biotechnol J. 2015;13:1121-35.

42. Thuenemann EC, Meyers AE, Verwey J, Rybicki EP, Lomonossoff GP. A method for rapid production of heteromultimeric protein complexes in plants: assembly of protective bluetongue virus-like particles. Plant Biotechnol J. 2013;11:839-46.

43. Van Zyl AR, Meyers AE, Rybicki EP. Transient Bluetongue virus serotype 8 capsid protein expression in Nicotiana benthamiana. Biotechnol Rep (Amst). 2016;9:15-24.

44. Dennis SJ, Meyers AE, Guthrie AJ, Hitzeroth II, Rybicki EP. Immunogenicity of plant-produced African horse sickness virus-like particles: implications for a novel vaccine. Plant Biotechnol J. 2018;16:442-50.

45. Dennis SJ, O'Kennedy MM, Rutkowska D, Tsekoa T, Lourens CW, Hitzeroth II, Meyers AE, Rybicki EP. Safety and immunogenicity of plant-produced African horse sickness virus-like particles in horses. Vet Res. 2018:49:105.

46. Strasser R, Stadlmann J, Schähs M, Stiegler G, Quendler H, Mach L, Glössl J, Weterings K, Pabst M, Steinkellner H. Generation of glyco-engineered Nicotiana benthamiana for the production of monoclonal antibodies with a homogeneous human-like N-glycan structure. Plant Biotechnol J. 2008;6: 392-402.

47. Loudon PT, Hirasawaa T, Oldfield S, Murphy M, Roy P. Expression of the outer capsid protein VP5 of two bluetongue viruses and synthesis of chimeric double-Shelled virus-like particles using combinations of recombinant baculoviruses. Virology. 1991;182:793-801.

48. Stewart M, Bhatia Y, Athmaran TN, Noad R, Gastaldi C, Dubois E, Russo P, Thiery R, Sailleau C, Breard E, Zientara S, Roy P. Validation of a novel approach for the rapid production of immunogenic virus-like particles for bluetongue virus. Vaccine. 2010;28:3047-54.

49. Matsuo E, Celma CC, Boyce M, Viarouge C, Sailleau C, Dubois E, Breard E, Thiery R, Zientara S, Roy P. Generation of replication-defective virus-based vaccines that confer full protection in sheep against virulent bluetongue virus challenge. J Virol. 2011;85:10213-21.

50. Celma CC, Boyce M, van Rijn PA, Eschbaumer M, Wernike K, Hoffmann B, Beer M, Haegeman A, De Clerq K, Roy P. Rapid generation of replicationdeficient monovalent and multivalent vaccines for bluetongue virus: protection against virulent virus challenge in cattle and sheep. J Virol. 2013; 87:9856-64.

51. van de Water SGP, van Gennip RGP, Potgieter CA, Wright IM, van Rijn PA. VP2 Exchange and NS3/NS3a Deletion in African horse sickness Virus (AHSV) in Development of Disabled Infectious Single Animal Vaccine Candidates for AHSV. J Virol. 2015:89:8764-72.

52. Lulla V, Lulla A, Wernike K, Aebischer A, Beer M, Roy P. Assembly of replication-Incompetent African horse sickness Virus particles: Rational Design of Vaccines for all serotypes. J Virol. 2016;90:7405-14.

53. Merlin M, Gecchele E, Capaldi S, Pezzotti M, Avesani L. Comparative evaluation of recombinant protein production in different biofactories: The green perspective. Biomed Res Int. 2014;136419:1-14.

54. Venter GJ, Koekemoer JJO, Paweska JT. Investigations on outbreaks of African horse sickness in the surveillance zone in South Africa. Rev Sci Tech. 2006;25(3):1097-109.

55. Thuenemann EC. PhD thesis. University of East Anglia, UK. Virus-like particle production using cowpea mosaic virus-based vectors; 2010.

56. Feenstra F, Pap JS, van Rijn PA. Application of Bluetongue Disabled Infectious Single Animal (DISA) vaccine for different serotypes by VP2 exchange or incorporation of chimeric VP2. Vaccine. 2015;33:812-8.

57. Mertens PP, Pedley S, Cowley J, Burroughs JN, Corteyn AH, Jeggo MH, Jennings DM, Gorman BM. Analysis of the roles of bluetongue virus outer capsid proteins VP2 and VP5 in determination of virus serotype. Virology. 1989:170:561-5.

58. Liu HM, Booth TF, Roy PJ. Interactions between bluetongue virus core and capsid proteins translated in vitro. J Gen Virol. 1992;73:2577-84.

59. DeMaula CD, Bonneau KR, MacLachlan NJ. Changes in the outer capsid proteins of bluetongue virus serotype ten that abrogate neutralization by monoclonal antibodies. Virus Res. 2000;67:59-66.

60. Wilken LR, Nikolov ZL. Recovery and purification of plant-made recombinant proteins. Biotechnol Adv. 2012;30:419-33.

61. Deville S, Carneaux E, Bertrand F, Cauchard S, Cauchard J, Dupuis L. Adjuvant Formulation for Companion Animals Vaccines. Procedia Vaccinol. 2011:4:104-12.

62. Crafford JE, Lourens CW, Smit TK, Gardner IA, MacLachlan NJ, Guthrie AJ. Serological response of foals to multivalent and monovalent live-attenuated African horse sickness virus vaccines. Vaccine. 2014;32(29):3611-6.

63. Molini U, Marucchella G, Maseke A, Ronchi GF, Di Ventura M, Salini R, Scacchia M, Pini A. Immunization of horses with a multivalent liveattenuated African horse sickness vaccine: Serological response and disease occurrence under field conditions. Trials Vaccinol. 2015;4:24-8.

64. Crafford JE, Lourens CW, Gardner IA, Maclachlan NJ, Guthrie AJ. Passive transfer and rate of decay of maternal antibody against African horse sickness virus in South African Thoroughbred foals. Equine Vet J. 2013;45:604-7.

65. Chhiba-Govindjee VP, Mathiba K, van der Westhuyzen CW, Steenkamp P, Rashamuse JK, Stoychev S, Bode ML, Brady D. Dimethylformamide is a novel nitrilase inducer in Rhodococcus rhodochrous. Appl Microbiol Biotechnol. 2018;102(23):10055-65.

66. Office International des Epizooties (OIE) Manual of Diagnostic Tests and Vaccines for Terrestrial Animals. http://www.oie.int/fileadmin/Home/eng/ Health_standards/tahm/2.05.01_AHS.pdf Accessed 20 July 2017.

67. House JA, Lombard M, Dubourget P, House C, Mebus CA. Further studies on the efficacy of an inactivated African horse sickness serotype 4 vaccine. Vaccine. 1994;12(2):142-4. 
68. von Teichman BF, Smit TK. Evaluation of the pathogenicity of African Horsesickness (AHS) isolates in vaccinated animals. Vaccine. 2008;26(39): 5014-21.

69. Martinelle L, Dal Pozzo F, Thys C, De Leeuw I, Van Campe W, De Clercq K, Thiry E, Saegerman C. Assessment of cross-protection induced by a bluetongue virus (BTV) serotype 8 vaccine towards other BTV serotypes in experimental conditions. Vet Res. 2018;49(1):63.

\section{Publisher's Note}

Springer Nature remains neutral with regard to jurisdictional claims in published maps and institutional affiliations.

- fast, convenient online submission

- thorough peer review by experienced researchers in your field

- rapid publication on acceptance

- support for research data, including large and complex data types

- gold Open Access which fosters wider collaboration and increased citations

- maximum visibility for your research: over $100 \mathrm{M}$ website views per year

At $\mathrm{BMC}$, research is always in progress. 